\title{
THE INFLUENCE OF SATISFACTION ON CONSUMER LOYALTY OF SUMAWE COFFEE MALANG
}

\author{
Yulita Anggraeni ${ }^{1}$, Dwi Retnoningsih ${ }^{2} *$, Abdul Wahib Muhaimin ${ }^{2}$ \\ ${ }^{1}$ Sudent at Agricultural Economics Department, UniversitasBrawijaya, Indonesia \\ ${ }^{2}$ Lecturer at Agricultural Economics Department, UniversitasBrawijaya, Indonesia \\ *corresponding author: dwi_sosek@yahoo.com
}

\begin{abstract}
The most famous coffee in Malang Regency is Amstirdam coffee and one of them is Sumawe coffee. Sumawe coffee is a robusta coffee from Sumbermanjing Wetan Sub District but not widely known yet. However this coffee has the potential of coffee to be improved to satisfy consumers. Producers who are able to satisfy consumers and have loyal consumers tend to survive in the competition. The purpose of this research is analyzing the influence of satisfaction on consumer loyalty Sumawe coffee. The sampling data was gathered from consumers Sumawe coffee with the number of sample is 40 respondents. The data are analyzed by using a Structural Equation Modeling Partial Least Square (SEM-PLS) technique. The results of analysis showed that product quality and price perception have a positive and significant influence on consumer satisfaction. Consumer satisfaction has a positive and significant influence on consumer loyalty. Product quality and price perception also have a positive and significant influence on consumer loyalty.
\end{abstract}

Keywords: consumer loyalty, consumer satisfaction, price perception, product quality, SEM-PLS

http://dx.doi.org/10.21776/ub.agrise.2019.019.1.3

Received 18 September 2018

Accepted 16 January 2019

Available online 2 March 2019

\section{INTRODUCTION}

Coffee is one of the plantation products that has high economic value, for Indonesia coffee has an important role in the formation of foreign exchange and employment providers (Dirjenbun 2016). Meanwhile, the growing trend of coffee consumption has caused many entrepreneurs to try to enter the coffee industry so that more and more competitors are emerging. In Malang Regency, the most famous local coffees are Amstirdam coffee (Ampelgading, Sumbermanjing Wetan, Tirtoyudo, and Dampit). Unfortunately coffee from Sumbermanjing Wetan which was named Sumawe coffee is not well known yet. Whereas sumawe coffee has the advantage of being local coffee that has been recognized for its quality as evidenced by the issuance of a taste test certificate from Association of Indonesian Coffee Exportes and
Industries (AICE) in Kontes Kopi Spesial Indonesia (KSSI) and its plan to develop agro coffee tourism in coffee cultivation locations.

The lack of recognition of this coffee is due to the weak branding of Sumawe coffee which is still inferior to other coffee and because consumers are more selective in determining the product to be purchased to make it satisfied. Paying attention to customer satisfaction is one way for consumers to remain loyal to Sumawe coffee products. In this research the level of satisfaction is influenced by product quality and price perception. This is also consistent with the opinion of Suwarni and Mayasari (2011) which states that affordable prices and good quality enable customer satisfaction and will attract new consumers so that they are expected to make loyal consumers in the end. Producers who are able to satisfy customers and have loyal customers tend to be able to survive in 
competition. Retnoningsih et al. (2014) also argues that companies which have competitiveness are able to produce high-quality products and services at lower cost. Based on the description, it is important to anlyze of consumer satisfaction and loyalty of Sumawe coffee Malang.

The purpose of this research is analyzing the influence of satisfaction on consumer loyalty Sumawe coffee. The data are analyzed by using a Structural Equation Modeling Partial Least Square (SEM-PLS) technique in order to examine the relationship between variables. The results of this research are expected to help producers in maintaining and developing Sumawe coffee in order to be able to compete with other types of coffee.

\section{RESEARCH METHODS}

This research was conducted in cafes that sell Sumawe coffee. The technique of determining respondents uses the accidental sampling method by observing SEM-PLS analysis criteria. According to Sholihin and Ratmono (2013) the sample size for testing models using SEM-PLS can be estimated with a small sample size ranging between $35-50$. In this research the number of sample used was 40 respondents from 10 times the number of variables. The general equation in this research is as follows:

$$
\begin{aligned}
& Y_{i}=\gamma_{i} X_{i}+\beta_{i} Y_{i}+\zeta_{i} \\
& X_{i}=\lambda_{i} X_{i . i}+\cdots \lambda_{n} X_{n . n}+\delta_{i} \\
& Y_{i . i}=\lambda_{i} Y_{i}+\cdots \lambda_{n} Y_{n}+\varepsilon_{i}
\end{aligned}
$$

Equation (1) is an inner model where $Y_{i}$, $X_{i}, \zeta_{i}, \gamma_{i}, \beta_{i}$ are dependent variables, independent variables, error equations, dependent-independent variable relationships, and dependent-dependent variable relations in $\mathrm{i}=1,2, \ldots, \mathrm{n}$. Equations (2) and (3) are outer models for formative and reflective variables where $X_{i . i}, Y_{i . i}$ are indicators of the dependent and independent variables. $\lambda_{i}, \delta_{i}, \varepsilon_{i}$ are the relationship of the variable with the indicator, the measurement error vector of the independent variable, and the dependent error vector.

SEM-PLS is used to design a variable relationship with the indicator. In this research there are 4 variables, namely product quality (X1), price perception (X2), customer satisfaction (Y1), and consumer loyalty (Y2). The path diagram images in this research are as follows.

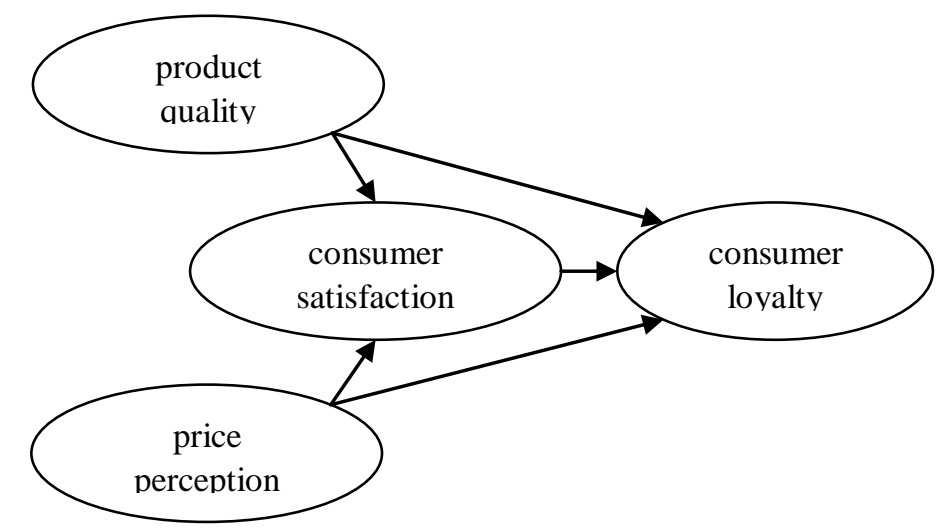

Figure 1. Path Diagram

\section{RESULTS AND DISCUSSION}

\section{Characteristics of Respondents}

Respondents in this study were consumers who had consumed Sumawe coffee. The number of consumers taken as respondents is 40 people with different characteristics.

Table 1 shows that there are differences in the percentage of respondents' characteristics. Based on gender, most respondents are male $(62.5 \%)$ with the age range 46-65 years (42.5\%). Most of them have an education level until senior high school $(40 \%)$. Where 14 out of 40 respondents are enterpreneurs $(35 \%)$ with an income $\geq \mathrm{Rp}$ 2,000,001 (62.5\%). Most respondents are consuming Sumawe coffee for $>6$ times $(80 \%)$ and they know the information from family (72.5\%).

\section{Descriptive Statistics}

Descriptive statistics in this research are used to see the mean value of the indicators in each variable. 
Respondents in this research were asked to answer questions regarding the variables that had been submitted. The rating scale used is the 1-5 likert scale. The scale shows respondents' responses ranging from 1 (strongly disagree), 2 (disagree), 3 (neutral), 4 (agree), and 5 (strongly agree). The explanation of descriptive statistics can be seen in Table 2.

Table 1. Characteristics of Respondents

\begin{tabular}{|c|c|c|c|}
\hline & Criteria & People & Percentage $(\%)$ \\
\hline \multirow{2}{*}{ Gender } & Male & 25 & 62.5 \\
\hline & Female & 15 & 37.5 \\
\hline \multirow{5}{*}{ Age (years) } & $\leq 25$ & 9 & 22.5 \\
\hline & $26-45$ & 13 & 32.5 \\
\hline & $46-65$ & 17 & 42.5 \\
\hline & $66-85$ & 0 & 0 \\
\hline & $\geq 86$ & 1 & 2.5 \\
\hline \multirow{4}{*}{ Education } & Elementary School & 11 & 27.5 \\
\hline & Junior High School & 11 & 27.5 \\
\hline & Senior High School & 16 & 40 \\
\hline & Bachelor & 2 & 5 \\
\hline \multirow{5}{*}{ Jobs } & Students & 6 & 15 \\
\hline & Employee & 8 & 20 \\
\hline & Entrepreneur & 14 & 35 \\
\hline & Housewafe & 3 & 7.5 \\
\hline & Others & 9 & 22.5 \\
\hline \multirow{5}{*}{ Income } & $\leq \mathrm{Rp} 500.000$ & 1 & 2.5 \\
\hline & Rp500.001-Rp1.000.000 & 2 & 5 \\
\hline & Rp1.000.001-Rp1.500.000 & 3 & 7.5 \\
\hline & Rp1.500.001-Rp2.000.000 & 9 & 22.5 \\
\hline & $\geq \mathrm{Rp} 2.000 .001$ & 25 & 62.5 \\
\hline \multirow{4}{*}{$\begin{array}{l}\text { Consumption } \\
\text { Intensity }\end{array}$} & $1-2$ times & 3 & 7.5 \\
\hline & 3-4 times & 1 & 2.5 \\
\hline & 5-6 times & 4 & 10 \\
\hline & $>6$ times & 32 & 80 \\
\hline \multirow{5}{*}{ Resources } & Friends & 6 & 15 \\
\hline & Family & 29 & 72.5 \\
\hline & Salespeople & 1 & 2.5 \\
\hline & $\begin{array}{l}\text { Advertising/ Promotion/ } \\
\text { Social Media }\end{array}$ & 0 & 0 \\
\hline & Other & 4 & 10 \\
\hline
\end{tabular}

Source: primary data analyzed

Table 2. Descriptive Statistics

\begin{tabular}{clc}
\hline Code & \multicolumn{1}{c}{ Item } & Mean \\
\hline $\mathrm{X}_{1}$ & Product quality & 4.475 \\
$\mathrm{X}_{1.1}$ & Coffee taste & 4.525 \\
$\mathrm{X}_{1.2}$ & Coffee aroma & 4.425 \\
$\mathrm{X}_{2}$ & Price perceptions & 4.408 \\
$\mathrm{X}_{2.1}$ & Affordability of prices & 4.650 \\
$\mathrm{X}_{2.2}$ & Conformity price & 4.275 \\
$\mathrm{X}_{2.3}$ & Price variation & 4.300 \\
$\mathrm{Y}_{1}$ & Consumer satisfaction & 4.500 \\
$\mathrm{Y}_{1.1}$ & Conformity with expectations & 4.525 \\
$\mathrm{Y}_{1.2}$ & Product satisfaction & 4.475 \\
$\mathrm{Y}_{2}$ & Consumer loyalty & 4.475 \\
$\mathrm{Y}_{2.1}$ & Recommend to others & 4.725 \\
$\mathrm{Y}_{2.2}$ & Positive things to the product & 4.050 \\
$\mathrm{Y}_{2.3}$ & Making a buyback & 4.650 \\
\hline
\end{tabular}

Source: primary data analyzed 
Based on Table 2, it is known that the average value of all indicators is 4 . It shows that the average respondent agrees with the statement submitted by the researcher.

\section{SEM-PLS}

In this research the data were analyzed using SEMPLS. The stages in conducting SEM-PLS analysis are through evaluation of outer model and evaluation of inner model. Table 3-6 describes the evaluation of outer model and Table 7-9 describes the inner model evaluation.

Table 3. Reliability Indicators (Formative)

\begin{tabular}{lccccc}
\hline & $\mathrm{X}_{1}$ & $\mathrm{X}_{2}$ & $\mathrm{Y}_{1}$ & VIF & Pvalue \\
\hline $\mathrm{X}_{1.1}$ & $(0.551)$ & 0.000 & 0.000 & 1,713 & $<0,001$ \\
$\mathrm{X}_{1.2}$ & $(0.551)$ & 0.000 & 0.000 & 1,713 & $<0,001$ \\
$\mathrm{X}_{2.1}$ & 0.000 & $(0,437)$ & 0.000 & 1,245 & $<0,001$ \\
$\mathrm{X}_{2.2}$ & 0.000 & $(0,439)$ & 0.000 & 1,251 & $<0,001$ \\
$\mathrm{X}_{2.3}$ & 0.000 & $(0,438)$ & 0.000 & 1,249 & $<0,001$ \\
$\mathrm{Y}_{1.1}$ & 0.000 & 0.000 & $(0,540)$ & 2,046 & $<0,001$ \\
$\mathrm{Y}_{1.2}$ & 0.000 & 0.000 & $(0,540)$ & 2,046 & $<0,001$ \\
\hline
\end{tabular}

Source: primary data analyzed

In the formative variables, all indicators have a $P$ value $<0.05$ and with a VIF value of $<3.3$ that meets the criteria of reliability indicators which means that the data has been reliable and there is no problem of collinearity.

Table 4. ReliabilityIndicators (Reflective)

\begin{tabular}{cccccc}
\hline & $\mathrm{X}_{1}$ & $\mathrm{X}_{2}$ & $\mathrm{Y}_{1}$ & $\mathrm{Y}_{2}$ & Pvalue \\
\hline $\mathrm{Y}_{2.1}$ & 0.174 & -0.122 & -0.134 & $(0.928)$ & $<0,001$ \\
$\mathrm{Y}_{2.3}$ & -0.174 & 0.122 & 0.134 & $(0.928)$ & $<0,001$ \\
\hline
\end{tabular}

Source: primary data analyzed

In the reflective variable, all indicators have fulfilled the criteria which is loading facotr values must be greater than 0.7 . It shows that the indicator on the reflective variable has met the criteria so that it can be stated that all variables are reliable.

Table 5. Internal Consistency Reliability and Convergent Validity

\begin{tabular}{ccccc}
\hline & $\mathrm{X}_{1}$ & $\mathrm{X}_{2}$ & $\mathrm{Y}_{1}$ & $\mathrm{Y}_{2}$ \\
\hline Composite reliability & 0.903 & 0.805 & 0.923 & 0.925 \\
AVE & 0.823 & 0.579 & 0.857 & 0.861 \\
\hline
\end{tabular}

Source: primary data analyzed

Composite reliability value has met the criteria that is greater than 0.7 , which means that all indicators have been able to measure each variables well. AVE value in this research has also met the criteria of $>0.5$ which means that $>50 \%$ of indicators are able to be explained.

Table 6. Discriminant Validity

\begin{tabular}{ccccc}
\hline & $\mathrm{X}_{1}$ & $\mathrm{X}_{2}$ & $\mathrm{Y}_{1}$ & $\mathrm{Y}_{2}$ \\
\hline $\mathrm{X}_{1}$ & $(0.907)$ & 0.516 & 0.359 & 0.636 \\
$\mathrm{X}_{2}$ & 0.516 & $(0.761)$ & 0.509 & 0.590 \\
$\mathrm{Y}_{1}$ & 0.359 & 0.509 & $(0.925)$ & 0.385 \\
$\mathrm{Y}_{2}$ & 0.636 & 0.590 & 0.385 & $(0.908)$ \\
\hline
\end{tabular}

Source: primary data analyzed 
Discriminant validityis known by looking at the square root value of AVEs and the correlation between variables. It is known that all the square roots of AVE in each variable shown in parentheses are greater than the other variables so that they have met the criteria of discriminant validity.

Table 7. R-square and Q-square

\begin{tabular}{ccc}
\hline & $\mathrm{Y}_{1}$ & $\mathrm{Y}_{2}$ \\
\hline R-square & 0.567 & 0.642 \\
Q-square & 0.550 & 0.661 \\
\hline
\end{tabular}

Source: primary data analyzed

R-square value of the customer satisfactionvariable is 0.567 , which means that the product quality and price perception variables are able to explain the variables of customer satisfaction by $56.7 \%$ and the remaining $43.3 \%$ are explained by other variables outside the model. The R-square value on the variable of consumer loyalty is 0.642 , which means that the variables of product quality, price perception, and customer satisfaction are able to explain the variables of consumer loyalty by $64.2 \%$ and the remaining $35.8 \%$ are explained by other variables outside the model. The Q-square value is 0.550 and 0.661 , which means the model has predictive relevance $(\mathrm{Q}$-square $>0)$.

Table 8. Effect Size

\begin{tabular}{cccc}
\hline & $\mathrm{X}_{1}$ & $\mathrm{X}_{2}$ & $\mathrm{Y}_{1}$ \\
\hline $\mathrm{Y}_{1}$ & 0.217 & 0.349 & \\
$\mathrm{Y}_{2}$ & 0.178 & 0.282 & 0.182 \\
\hline
\end{tabular}

Source: primary data analyzed

The results show that the product quality variable has an intermediate influence on the structural level on consumer satisfaction and consumer loyalty $(0.217$ and $0.178 \geq 0.15)$. Price perception variables have a large influence on the structural level on consumer satisfaction $(0.349 \geq$ 0.35 ) and intermediate influence on the structural level on consumer loyalty $(0.282 \geq 0.15)$. Consumer satisfaction variable has an intermediate influence on the structural level on consumer loyalty $(0.182 \geq 0.15)$.

P-values of APC, ARS, and AARS are respectively $0.003,<0.001$, and $<0.001$, which means that the model has met the criteria for the model fit (Pvalue <0.05). AVIF and AFVIF are 1.647 and 2.078, which means that they have fulfilled the requirements $(<3.3)$, indicating that there is no problem of collinearity in the model.
Table 9. Goodness of Fit (GoF)

\begin{tabular}{|c|c|c|}
\hline & Value & $\mathrm{P}$ value \\
\hline $\begin{array}{l}\text { Average path coefficient } \\
\text { (APC) }\end{array}$ & 0.358 & 0.003 \\
\hline Average $R$-squared (ARS) & 0.604 & $<0.001$ \\
\hline $\begin{array}{l}\text { Average adjusted } R \text {-squared } \\
\text { (AARS) }\end{array}$ & 0.578 & $<0.001$ \\
\hline Average block VIF (AVIF) & 1.647 & \\
\hline $\begin{array}{l}\text { Average full collinearity VIF } \\
\text { (AFVIF) }\end{array}$ & 2.078 & \\
\hline
\end{tabular}

Table 10. Direct, Indirect, and Total Effect Values

\begin{tabular}{|c|c|c|c|c|}
\hline $\begin{array}{c}\text { Path } \\
\text { Correlation }\end{array}$ & $\begin{array}{l}D i \\
\text { rect }\end{array}$ & $\begin{array}{l}\text { Indi } \\
\text { rect }\end{array}$ & Total & $\begin{array}{c}\mathrm{P} \\
\text { value }\end{array}$ \\
\hline product quality & & & & \\
\hline $\begin{array}{l}\rightarrow \text { consumer } \\
\text { satisfaction } \\
\text { price }\end{array}$ & 0.350 & - & 0.350 & $<0.01$ \\
\hline $\begin{array}{l}\text { perceptions } \rightarrow \\
\text { consumer } \\
\text { satisfaction }\end{array}$ & 0.505 & - & 0.505 & $<0.01$ \\
\hline $\begin{array}{l}\text { consumer } \\
\text { satisfaction } \\
\rightarrow \text { consumer } \\
\text { loyalty } \\
\text { product quality }\end{array}$ & 0.277 & - & 0.277 & 0.03 \\
\hline $\begin{array}{l}\rightarrow \text { consumer } \\
\text { loyalty }\end{array}$ & 0.265 & 0.097 & 0.362 & $<0.01$ \\
\hline $\begin{array}{l}\text { price } \\
\text { perceptions } \rightarrow \\
\text { consumer } \\
\text { loyalty }\end{array}$ & 0.393 & 0.140 & 0.533 & $<0.01$ \\
\hline
\end{tabular}

Based on Table 10 it is known that all variables have a positive and significant influence so that the hypothesis is accepted (accept $\mathrm{H}_{\mathrm{a}}$, reject $\mathrm{H}_{0}$ ). In addition, there are also two indirect relationships, namely the effect of product quality variable on consumer loyalty mediated by variable of customer satisfaction and the influence of price perception variable on consumer loyalty mediated by consumer satisfaction variable. Both mediation relationships are partially mediated because they have an indirect path coefficient value that decreases but remains significant.

\section{Discussion}

There are several findings in this research that is the product quality variable has a positive and significant influence on the variable of customer satisfaction $(\beta=0.350$ and $P<0.01)$. This is in 
accordance with a statement from Lestari, Haryanto, and Mawardi (2009) which stated that coffee drinks naturally contain many distinctive flavors and aromas that are able to provide pleasure and satisfaction for the drinker. Razak, Nirwanto, and Triatmanto (2016) also argue that the quality of products is not viewed from the perspective of the producer but through a consumer perspective, if the perceived quality of the product is in line with expectations, consumers will perceive the quality of the product as good quality and also satisfied. Price perception variables also have a positive and significant influence on consumer satisfaction $(\beta=$ 0.505 and $\mathrm{P}<0.01)$. Kurniawan, Satria, and Suprayitno (2016) stated that prices have a positive influence with satisfaction. If the price is set according to the benefits received by consumers, it will cause consumers to feel satisfied with the product.

Variable consumer satisfaction has a positive and significant influence on consumer loyalty $(\beta=$ 0.277 and $\mathrm{P}=0.03$ ). This is consistent with the research of Kusumasasti, Andarwati, and Hadiwidjojo (2017) that customer satisfaction has a large influence on loyalty can be shown by the willingness of the customer to recommend to others. Supported by the opinion of Joko, Nurliza, and Komariyati (2015) which stated that if consumers feel satisfaction with certain products, there will be a commitment to repurchase.

Based on data analysis, it is also known that product quality variables have a positive and significant effect on consumer loyalty $(\beta=0.265$ and $\mathrm{P}=0.03$ ). In line with the research of Mangore, Lumanauw, and Tielung (2015) which stated that consumers will become loyal if the product offered a high quality, meaning that a quality product is a product that is able to produce results that exceed consumer expectations. Price perception variables also have a positive and significant influence on consumer loyalty $(\beta=0.393$ and $\mathrm{P}<0.01)$. Supported by research from Hermawan et al.(2017) which states that price perception has a positive influence in increasing consumer loyalty which producers will set reasonable prices and adapt to customer conditions in order to gain customer loyalty and can provide benefits to producers. In addition, findings also found that product quality and price perception have a direct and indirect influence on consumer loyalty.

\section{CONCLUSION}

Based on the results, it is known that there is an influence on satisfaction to consumer loyalty. The satisfaction is influenced by product quality and price perception. Good quality product and good price perception will increase consumer satisfaction with Sumawe coffee which is directly proportional to the increase in consumer loyalty. This consumer loyalty can be seen with consumers making a repurchases, recommend and express positive things about Sumawe coffee to others.

Unfortunately, this research only discusses the effect of product quality and price perception on customer satisfaction and loyalty. So that for further research it is suggested to study more deeply about other variables that influence the satisfaction and loyalty of Sumawe coffee consumers, such as service, promotion, location, brand awareness and other related variables in order to get more accurate results.

\section{REFERENCES}

Dirjenbun. 2016. Statistik Perkebunan Indonesia Komoditas Kopi 2015-2017. Jakarta: Sekretariat Direktorat Jenderal Perkebunan.

Hermawan, Bambang, Salim Basalamah, Asdar Djamereng, and Annas Plyriadi. 2017. "Effect of Service Quality and Price Perception on Corporate Image , Customer Satisfaction and Customer Loyalty among Mobile Telecommunication Services Provider." International Journal of Management \& Social Sciences 8(1):62-73.

Joko, Nurliza, and Komariyati. 2015. "Analisis Brand Equity Teh Celup Sariwangi Terhadap Loyalitas Konsumen (Studi Kasus Di Supermarket Kota Pontianak)." AGRISE 15(2):126-35.

Kurniawan, Hendra, Arif Satria, and Gendut Suprayitno. 2016. "Perancangan Strategi Bauran Pemasaran Untuk Meningkatkan Kepuasan Dan Loyalitas Nasabah Pembiayaan Umrah." Jurnal Aplikasi Bisnis Dan Manajemen 2(1):32-42.

Kusumasasti, Ika, Andarwati, and Djumilah Hadiwidjojo. 2017. "Pengaruh Kualitas Produk Dan Layanan Terhadap Loyalitas Pelanggan Coffee Shop." Ekonomi Bisnis 22(2):123-29.

Lestari, Endang Wiji, Idha Haryanto, and Surip Mawardi. 2009. "Konsumsi Kopi Masyarakat Perkotaan Dan Faktor-Faktor Yang Berpengaruh : Kasus Di Kabupaten Jember." Pelita Perkebunan 25(3):216-35. 
Mangore, Indah Indria, Bode Lumanauw, and Maria Tielung. 2015. "Analisis Kualitas Produk, Kualitas Pelayanan Dan Citra Merek Terhadap Loyalitas Konsumen Tupperware Manado.” Jurnal EMBA 3(2):616-27.

Razak, Ismail, Nazief Nirwanto, and Boge Triatmanto. 2016. "The Impact of Product Quality and Price on Customer Satisfaction with the Mediator of Customer Value." Journal of Marketing and Consumer Research 30(1):59-68. Retrieved (http://iiste.org/Journals/index.php/JMCR/arti cle/view/34735).

Retnoningsih, Dwi, Moch.Muslich Mustadjab, Nuhfil Hanani, and Grace Tsai. 2014.
"Hubungan Rantai Pasok (Supply Chain Relationship) Dan Daya Saing Usaha Kecil Menengah (UKM) Sari Apel Di Kota Batu." AGRISE 14(1):36-47.

Sholihin, Mahfud and Dwi Ratmono. 2013. Analisis SEM-PLS Dengan WarpPLS 3.0. Yogyakarta: ANDI.

Suwarni and Septina Dwi Mayasari. 2011. "Pengaruh Kualitas Produk Dan Harga Terhadap Loyalitas Melalui Kepuasan Konsumen." Jurnal Ekonomi Bisnis 16(1):76-84. 